\title{
PENGELOLAAN PEMBELAJARAN AKUNTANSI DI SMK
}

\author{
Lilis Retno Utami ${ }^{1}$ dan Tjipto Subadi ${ }^{2}$ \\ ${ }^{1)}$ SMK Negeri 1 Sragen \\ 2) Dosen Magister Administrasi Pendidikan Pascasarjana UMS \\ email: lilisretnoutami1982@gmail.com
}

\begin{abstract}
The aims of the research are to describe planning, organizing, actuating and evaluating of Accounting Learning At State Vocational High School 1 of Sragen. The research type is qualitative research with etnography design. Data were collected by interview, observation and documentation. Data analysis technique used an interactive model of analysis. Results of this research are: 1) Accounting RPP preparation begins with studying the content standards, competency standards, syllabus, prepare lesson plans, 2) Organizing Accounting learning includes organizing the subject matter sequentially in accordance with the syllabus reference, academic calendar, class, difficult subject matter and to find a settlement, 3) Accounting learning process begins with teachers delivering salutation, attention or observation of hygiene class, do absent students, check homework assignments, and motivates students, 4) Accounting learning evaluation by sharing test questions to students. Accounting learning practice test indicated by the ability to make financial reports. Teachers do remedial to students who have value below the minimum completeness criteria, instead of teachers provide enrichment for students who value above minimum completeness criteria. Spesific model of Accounting learning is scientific performance sheet.
\end{abstract}

Keywords: planning, organizing, actuating, evaluating, accounting learning

Abstrak: Tujuan penelitian ini mendeskripsikan perencanaan, pengorganisasian, pelaksanaan dan evaluasi pembelajaran Akuntansi di SMK N 1 Sragen. Jenis penelitian kualitatif dengan desain etnografi. Pengumpulan data dengan teknik wawancara mendalam, observasi dan dokumentasi. Teknik analisis data menggunakan analisis model interaktif. Hasil penelitian disimpulkan: 1) Penyusunan RPP Akuntansi diawali dengan mempelajari standar isi, standar kompetensi, silabus, menyiapkan RPP, 2) Pengorganisasian pembelajaran Akuntansi meliputi pengorganisasian materi pelajaran secara berurutan sesuai dengan acuan silabus, kalender akademik, kelas, kesulitan materi pelajaran dan mencarikan penyelesaian; 3) Proses pembelajaran Akuntansi diawali dengan guru menyampaikan salam pembukaan, memperhatikan atau pengamatan kebersihan kelas, melakukan absen siswa, cek tugas PR, serta memotivasi siswa, 4) Evaluasi pembelajaran Akuntansi dengan membagikan soal tes kepada siswa. Tes praktik pembelajaran Akuntansi ditunjukkan dengan kemampuan membuat laporan keuangan. Guru melakukan remidi kepada siswa yang nilainya di bawah KKM, sebaliknya guru memberikan pengayaan bagi siswa yang nilainya di atas KKM. Model evaluasi khusus Pembelajaran Akuntansi yaitu lembar kinerja ilmiah.

Kata Kunci: perencanaan, pengorganisasian, pelaksanaan, penilaian, pembelajaran Akuntansi 


\section{Pendahuluan}

Akuntansi merupakan salah satu kompetensi keahlian yang ada di SMK Negeri 1 Sragen yang saat ini mempunyai 5 rombongan belajar untuk masing-masing tingkat. Jumlah siswa kelas X, XI, dan XII untuk kompetensi keahlian Akuntansi sebanyak 480 siswa. Prestasiyang dicapai pada kompetensi keahlian akuntansi yaitu pernah menjadi juara I lomba kompetensi siswa tingkat Kabupaten Sragen. Sesuai dengan visi SMK Negeri 1 Sragen yaitu Mewujudkan SMK Negeri 1 Sragen sebagai penghasil sumber daya manusia yang profesional, berbudi luhur, berwawasan teknologi, dan mandiri dalam bidang Bisnis Manajemen dan Teknologi Informasi dan Komunikasi yang mampu menjawab tantangan zaman. Untuk itu salah satu tujuan kompetensi keahlian Akuntansi di SMK Negeri Sragen adalah menjadi tenaga kerja tingkat menengah untuk mengisi kebutuhan dunia usaha dan industri pada saat ini maupun masa yang akan datang dalam lingkup keahlian bisnis dan manajemen, khusus akuntansi.

Agar keberhasilan tujuan pembelajaran Akuntansi dapat tercapai dengan baik maka diperlukan pengelolaan pembelajaran. Pengelolaan diartikan sebagai suatu metode/ teknik atau proses untuk mencapai suatu tujuan tertentu secara sistematik dan efektif, melalui tindakan-tindakan perencanaan (planning), pengorganisasian (organizing), pelaksanaan (actuating) dan pengawasan (controlling) dengan menggunakan sumber daya yang ada secara efisien (Kodoatie dan Sjarief, 2010: 348).

Mata pelajaran Akuntansi sebagai mata pelajaran produktif yang diajarkan kepada siswa jurusan Akuntansi menjadi mata pelajaran yang wajib dikuasai siswa jurusan tersebut. Pengelolaan pembelajaran Akuntansi di SMK Negeri 1 Sragen yang dilaksanakan akan mempengaruhi kepribadian, perilaku, pengetahuan dan keterampilan siswa setelah mengikuti proses pembelajaran. Artinya, berhasil tidaknya proses pembelajaran akan sangat ditentukan oleh pengelolaan pembelajaran Akuntansi di SMK Negeri 1 Sragen.

Secara umum tujuan penelitian ini adalah untuk mendeskripsikan pengelolaan pembelajaran Akuntansi di SMK N 1 Sragen. Selanjutnya secara khusus tujuan penelitian ini untuk mendeskripsikan: 1) perencanaan pembelajaran Akuntansi di SMK N 1 Sragen, 2) pengorganisasian pembelajaran Akuntansi di SMK N 1 Sragen, 3) pelaksanaan pembelajaran Akuntansi di SMK N 1 Sragen, dan 4) evaluasi pembelajaran Akuntansi di SMK N 1 Sragen.

\section{Metode}

Jenis penelitian ini adalah penelitian kualitatif dengan menggunakan desain etnografi. Menurut Moleong (2009: 235-236) etnografi memfokuskan diri pada budaya dari sekelompok orang.

Lokasi penelitian adalah di SMK N 1 Sragen selama tiga bulan yang dimulai pada bulan Juli 2015 sampai dengan September 2015. Narasumber penelitian ini adalah kepala sekolah, guru dan pihak lain yang dapat memberikan data.

Teknik pengumpulan data melalui wawancara mendalam, observasi dan dokumentasi. Menurut Subadi, dkk. (2013: $105)$ proses wawancara yang digunakan pemahaman urutan pertama (the first order understanding) dan pemahaman urutan kedua (the second order understanding). Observasi dilakukan dengan mengamati/ memandang/ dan/ atau mendengarkan orang atau kejadian. Hasilnya yang telah terkuak kemudian dicatat (Sutama, 2010: 92). Dokumen sering dipakai sebagai sumber data dalam penelitian sebab dalam beberapa hal dokumen dapat dimanfaatkan untuk menguji, menafsirkan, bahkan meramalkan (Moleong, 2009: 217).

Teknik keabsahan data yang digunakan dalam penelitian ini adalah triangulasi model sumber. Teknik analisa data yang digunakan dalam penelitian ini adalah analisis model interaktif (Interactive Model of Analysis). Miles dan Huberman (2008: 16) menyebutkan analisis model ini terdiri dari tiga komponen, 
yaitu reduksi data, sajian data dan penarikan kesimpulan.

\section{Hasil dan Pembahasan}

1. Rencana Pelaksanaan Pembelajaran Akuntansi di SMK Negeri 1 Sragen

Rencana pelaksanaan pembelajaran Akuntansi di SMK Negeri 1 Sragen merupakan kegiatan dalam pembelajaran Akuntansi. Dalam perencanaan ini, kegiatan awal yang dilakukan adalah mempelajari Standar isi, Standar Kompetensi dan mempelajari silabus. Kegiatan ini dilakukan untuk penyesuaian kalender akademik. Kegiatan ini juga dilakukan agar guru Akuntansi sudah siap untuk memberikan pengajaran dikarenakan guru tersebut telah mempelajarinya terlebih dahulu. Hal ini didukung dengan hasil penelitian dari Deviarti, et.al. (2012) bahwa pengetahuan guru yang kurang mengenai perubahan standar memerlukan pelatihan dan buku teks terhadap guru. Oleh karena itu, kegiatan mempelajari standar isi, standar kompetensi dan silabus sangat diperlukan untuk kesiapan guru dalam melaksanakan pembelajaran Akuntansi.

Setelah kegiatan-kegiatan di atas dilakukan, kegiatan selanjutnya adalah guru akuntansi harus menyiapkan RPP, terdiri dari mata pelajaran, kelas/ semester, pertemuan, alokasi waktu, SK (Standar Kompetensi), KD (kompetensi dasar), indikator, tujuan pembelajaran, materi ajar, metode pembelajaran, alat/ bahan/ sumber belajar, langkah-langkah pembelajaran, penilaian. RPP adalah pedoman bagi guru dalam pelaksanaan pembelajaran baik itu pembelajaran di dalam kelas, laboratorium, ataupun di lapangan untuk tiap kompetensi dasar. Dengan demikian, hal-hal yang tercantum pada RPP mencantumkan persoalan yang berkaitan langsung dengan kegiatan pembelajaran dengan usaha untuk menguasai suatu Kompetensi Dasar yang sudah ditetapkan.

Kegiatan selanjutnya yang harus dilakukan oleh guru akuntansi adalah mengisi RPP berdasarkan panduan pengisian dari MGMP dan menyesuaikan kondisi sekolah. Agar penyusunan RPP dapat lebih terarah, maka guru Akuntansi perlu mengikuti panduan yang disediakan oleh MGMP. Seorang guru Akuntansi juga perlu memperhatikan kondisi sekolahnya agar di dalam pengisian RPP dapat disesuaikan dengan kondisi sekolahnya tersebut. Seperti hasil penelitian dari Dockter (2014) bahwa kondisi sekolah yang menerapkan teknologi canggih dapat meningkatkan lingkungan belajar siswa dalam pembelajaran Akuntansi. Akibatnya, lingkungan belajar menjadi lebih efisien dan efektif, menguntungkan baik guru dan siswa.

Penyusunan rencana pembelajaran selanjutnya adalah guru akuntansi menyebutkan standar kompetensi pelajaran akuntansi yang terdapat dalam silabus. Temuan ini bertentangan dengan hasil penelitian dari Deviarti, et.al. (2012) bahwa kurikulum dan buku teks Akuntansi saat ini tidak selaras dengan perubahan Standar Akuntansi Indonesia. Hal ini disebabkan karena kurangnya pengetahuan guru akuntansi mengenai perubahan standar sehingga sangat diperlukan sekali pelatihan-pelatihan bagi guru Akuntansi.

Kegiatan penyusunan rencana pembelajaran selanjutnya adalah guru akuntansi menyebutkan alat-alat praktik dalam alat/bahan/sumber belajar seperti Kuitansi, buku besar, buku laporan keuangan, komputer, kalkulator, dan lain-lain. Penggunaan sumber atau bahan pembelajaran ini sangat penting untuk menunjang kegiatan pembelajaran Akuntansi. Hal ini diperkuat dengan hasil penelitian dari Fentim (2014) bahwa guru Akuntansi Keuangan mengakui pentingnya sumber/ bahan pembelajaran dalam pembelajaran akuntansi keuangan tetapi mereka tidak bisa menggunakan sumber daya ini untuk mendukung pengajaran mereka. Umumnya mereka menggunakan sumber/ bahan pembelajaran berupa kapur atau papan tulis dan buku kecil Akuntansi Keuangan. Oleh sebab itu guru Akuntansi hendaknya mempelajari terlebih dahulu dalam menetapkan sumber atau bahan pembelajaran 
supaya pencapaian sasaran pembelajaran dalam kegiatan belajar mengajar bisa efektif digunakan.

Penyusunan rencana pembelajaran selanjutnya yaitu guru akuntansi harus mengkonsultasikan dan mensyahkan RPP kepada Kepala Sekolah. Jika dalam proses konsultasi tersebut masih terdapat RPP yang perlu direvisi maka perlu segera diperbaiki dan dikonsultasikan kembali kepada kepala sekolah. Selanjutnya, apabila sudah disyahkan oleh kepala sekolah maka perlu dilakukan penjilidan, pengadministrasian dan pendokumentasian RPP. Hal ini seperti yang disampaikan oleh Sagala (2009) bahwa perencanaan, dalam hal ini adalah penyusunan RPP merupakan hasil kesepakatan dan pengertian di antara personal sekolah tentang apa yang harus dicapai oleh sekolah. Melalui RPP yang optimal, guru bisa melakukan pengorganisasian kompetensi dasar yang hendak diraih pada proses pembelajaran dengan lebih terarah.

2. Pengorganisasian Pembelajaran Akuntansi di SMK Negeri 1 Sragen

Pengorganisasian pembelajaran Akuntansi di SMK Negeri 1 Sragen mengorganisasi materi pelajaran yang dilakukan secara berurutan sesuai dengan acuan silabus. Pengorganisasian materi pelajaran adalah salah satu faktor yang sangat penting pada kegiatan pembelajaran. Materi pelajaran itu disusun sebagai satu kesatuan yang utuh secara berurutan dan logis. Menurut Sutikno (2009) materi pelajaran merupakan medium untuk mencapai tujuan pembelajaran yang "dikonsumsi" oleh siswa. Oleh sebab itu dalam mengorganisasikan materi, seorang guru perlu memahami prinsip pengembangan kurikulum, struktur kurikulum, dan silabus yang telah ditetapkan dalam kurikulum.

Kegiatan pengorganisasian pembelajaran Akuntansi selanjutnya adalah guru Akuntansi perlu mengorganisir kalender akademik untuk pelaksanaan pelajaran praktik. Kegiatan ini dilakukan agar jadwal kegiatan praktik akuntansi, misalnya di laboratorium tidak bertabrakan dengan jadwal kegiatan praktik kelas lain. Selain itu, supaya dalam penggunaan waktu pembelajaran selama satu tahun dapat dibagi secara merata dan sebaik mungkin dalam meningkatkan kualitas pendidikan. Hal ini diperkuat oleh Ezeagba (2014) bahwa tujuan pendidikan kejuruan melalui pengetahuan akuntansi dan kompetensi yang diperlukan, oleh karena itu pemerintah harus melakukan segala kemungkinan untuk mencegah pengorganisasian kalender akademik yang tidak teratur.

Kegiatan mengorganisir pembelajaran Akuntansi selanjutnya adalah guru mengorganisir kelas agar tidak terjadi kegaduhan dengan pengawasan dan sanksi. Guna peningkatan peran guru dalam kegiatan pembelajaran dan prestasi belajar peserta didik, guru Akuntansi hendaknya dapat membuat lingkungan belajar menjadi efektif serta dapat melakukan pengelolaan kelas. Hal ini seperti yang disampaikan oleh Mulyono (2008) bahwa pengorganisasian merupakan menyusun hubungan perilaku yang efektif antarpersonalia, sehingga mereka dapat bekerja sama secara efisien dan memperoleh keputusan pribadi dalam melaksanakan tugastugas dalam situasi lingkungan yang ada guna mencapai tujuan dan sasaran tertentu. Sebab kelas adalah lingkungan belajar dan juga aspek lingkungan sekolah yang harus dilakukan pengorganisasian. Kelas harus dilakukan pengaturan dan pengawasan supaya aktivitas-aktivitas pembelajaran dapat terarah terhadap sasaran-sasaran pendidikan. Kelas yang baik merupakan kelas yang memiliki sifat memberikan tantangan dan rangsangan peserta didik agar mau belajar, memberi perasaan aman, nyaman dan kepuasan dalam meraih prestasi belajar yang diinginkan.

Pengorganisasian Pembelajaran Akuntansi di SMK selanjutnya adalah guru mengorganisir kesulitan-kesulitan materi pelajaran dan mencarikan penyelesaian. Kesulitan dalam menerima proses pembelajaran adalah persoalan wajar yang sering dialami siswa. Kerapkali ditemui 
terdapat peserta didik yang terjebak dalam kesulitan untuk menangkap pelajaran di sekolah. Membangun hubungan kepercayaan antara guru dengan peserta didik sangat penting bagi guru supaya peserta didik memiliki keinginan untuk mengungkap kesulitan yang dialami maupun masalah yang dihadapi. Hal ini diperkuat dengan hasil penelitian dari Ezeagba (2014) yaitu guru akuntansi harus memenuhi tanggung jawab mereka untuk memastikan siswa memiliki kinerja yang baik dalam pelajaran akuntansi. Oleh karena itu perlu adanya komunikasi antara guru dengan siswa.

3. Pelaksanaan pembelajaran Akuntansi di SMK Negeri 1 Sragen

Pelaksanaan pembelajaran Akuntansi di SMK Negeri 1 Sragen adalah diawali dengan guru harus menyampaikan salam pembukaan. Pada pembukaan pembelajaran umumnya diawali dengan guru Akuntansi memberikan salam pembuka bagi peserta didik, memperhatikan kebersihan kelas, dan mengabsen kehadiran siswa. Sesuai dengan pendapat Suryosubroto (2009) bahwa membuka pelajaran adalah usaha atau kegiatan yang dilakukan guru dalam kegiatan belajar mengajar untuk menciptakan pra kondisi bagi murid agar mental maupun perhatiannya terpusat pada apa yang dipelajarinya sehingga usaha tersebut akan memberikan efek terhadap kegiatan belajar. Dapat disimpulkan aktivitas salam pembukaan dilaksanakan khususnya untuk membuat kondisi awal dalam proses pembelajaran yang menyenangkan guna mendukung siswa untuk lebih fokus pada dirinya sendiri supaya dapat mengikuti kegiatan belajar mengajar dengan baik.

Setelah kegiatan absensi siswa dilakukan, maka pelaksanaan pembelajaran Akuntansi selanjutnya adalah guru melakukan pengecekan tugas Pekerjaan Rumah. Pekerjaan rumah (PR) adalah satu dari beberapa alat yang digunakan guru untuk memberikan peningkatan daya paham peserta didik. Hasil penelitian ini diperkuat oleh Popa, et.al. (2012) dimana pekerjaan rumah (PR) digunakan sebagai tugas individu siswa. Dengan memberikan peserta didik tugas rumah, guru berharap proses tercapainya sasaran pembelajaran dapat dijalankan secara dua arah yaitu di sekolah dan rumah.

Pelaksanaan pembelajaran Akuntansi juga diawali dengan guru memotivasi siswa dengan cara menjelaskan daya guna materi pelajaran Akuntansi. Guru semestinya dapat menumbuhkan perhatian dan memberikan motivasi kepada peserta didik sebelum aktivitas pembelajaran dilanjutkan dalam kegiatan inti. Hal ini seperti yang disimpulkan oleh Ezeagba (2014) dalam penelitiannya bahwa guru Akuntansi perlu memotivasi siswa agar memiliki kinerja yang baik dalam pelajaran akuntansi. Umumnya pikiran peserta didik masih ingat dengan materi pelajaran yang diberikan sebelumnya. Pada masalah ini guru perlu kejelian untuk menyiasati masalah tersebut. Guru hendaknya fokus dalam memberikan perhatian kepada peserta didik dengan cara memperlihatkan gambar atau alat peraga. Berikan cerita baru kepada siswa sehingga timbul pertanyaan, namun dengan catatan bahwa cerita tersebut terdapat hubungan dengan materi Akuntansi yang hendak dibahas.

Kegiatan setelah pemberian motivasi siswa adalah guru menjelaskan teori-teori akuntansi, memaparkan penerapan akuntansi dan membuat dokumen untuk mempraktekkan penggunaan akuntansi dalam kehidupan sehari-hari. Kegiatan ini termasuk kegiatan inti yaitu kegiatan penyampaian materi pelajaran sesuai dengan RPP yang telah dibuat. Kegiatan inti pembelajaran Akuntansi yaitu menyampaikan teori-teori akuntansi kemudian menerapkan dan mempraktekkan teori tersebut pada kehidupan sehari-hari. Diperkuat dengan hasil penelitian dari Popa, et.al. (2012) yang menunjukkan bahwa siswa diminta untuk menganalisis teks (bacaan) untuk mengidentifikasi hubungan antara pernyataan, pertanyaan, konsep, deskripsi, atau bentuk-bentuk representasi 
yang dimaksudkan untuk mengungkapkan keyakinan, penilaian, pengalaman, alasan, informasi atau pendapat. Selain itu, sebagai keterampilan berpikir kritis, digunakan dalam berbagai latihan, misalnya, siswa diminta untuk menghubungkan istilah "akuntansi" dan "pembukuan" sesuai dengan penjelasan mereka.

Kegiatan pembelajaran Akuntansi lainnya adalah guru memberikan kesempatan praktek kepada anak di laboratorium sekolah. Khusus untuk jurusan Akuntansi, siswa Akuntansi diberikan latihan praktek di Laboratorium Komputer Akuntansi, mereka dilatih cara menggunakan program MYOB dan Ms. Excell untuk mempraktekkan penerapan pencatatan Akuntansi menggunakan komputer. Praktek Akuntansi di laboratorium komputer Akuntansi ini merupakan bagian dari kemajuan teknologi. Diperkuat dengan hasil penelitian dari Dockter (2014) yang menunjukkan bahwa peningkatan pemanfaatan teknologi baru, perangkat lunak yang user-friendly, dan kemajuan bentuk sistem penyampaian pembelajaran memungkinkan guru untuk lebih melibatkan siswa dalam proses pembelajaran. Pengajar dapat menggabungkan penggunaan sistem proyeksi dengan paket software Excel untuk menggambarkan konsep dan prinsipprinsip akuntansi, seperti alokasi pajak yang ditangguhkan dan liabilitas selama beberapa periode. Selain menjadi alat pengajaran yang sangat efektif, para siswa mampu mengerjakan tugas dengan template aplikasi praktis yang dapat digunakan di lingkungan kerja mereka. Dapat disimpulkan bahwa kombinasi teknologi baru, seperti sistem informasi manajemen, dan penerapan metode pembelajaran yang berpusat pada siswa, seperti pembelajaran berbasis masalah, telah meningkatkan lingkungan belajar siswa dalam pembelajaran Akuntansi. Kontribusi dari teknologi canggih dan metode pembelajaran telah berperan dalam mendorong pembelajaran yang berpusat pada siswa.

\section{Evaluasi pembelajaran Akuntansi di SMK Negeri 1 Sragen}

Evaluasi pembelajaran Akuntansi di SMK Negeri 1 Sragen dilakukan dengan cara guru membagikan soal tes untuk evaluasi. Setelah tes selesai dikerjakan oleh siswa, guru dapat memberikan jawaban soal dalam LKS, agar dapat digunakan latihan bagi siswa. Menurut Sutikno (2009) kegiatan evaluasi digunakan untuk mengukur dan menilai seberapa jauh tujuan pembelajaran telah tercapai atau hingga mana terdapat kemajuan belajar siswa, dan bagaimana tingkat keberhasilan sesuai dengan tujuan pembelajaran tersebut. Guru Akuntansi yang telah selesai melakukan tes, maka guru perlu untuk memberikan jawaban-jawaban yang benar agar siswa yang tidak mengerti dengan soal tes tersebut tahu kesalahannya sehingga tujuan dari pembelajaran Akuntansi pun dapat tercapai.

Evaluasi pembelajaran Akuntansi selain dilakukan melalui tes teori Akuntansi juga dilakukan dengan tes kemampuan praktik membuat laporan keuangan. Tes ini penting bagi siswa agar dapat menerapkan teoriteori Akuntansi dengan praktik akuntansi di perusahaan jasa ataupun di perusahaan dagang. Evaluasi praktik pembelajaran Akuntansi dapat dilakukan dengan membuat laporan keuangan terhadap soal praktik Akuntansi yang diberikan oleh guru atau dapat dilakukan praktik di laboratorium komputer Akuntansi. Seperti yang disampaikan oleh Ezeagba (2014) bahwa laboratorium Akuntansi dapat meningkatkan pelajaran praktik. Evaluasi praktik pembelajaran Akuntansi, baik itu praktik membuat laporan keuangan secara manual atau menggunakan komputer bertujuan untuk memberikan pemahaman mengenai penerapan konsepkonsep Akuntansi pada praktik bisnis dunia nyata.

Berdasarkan evaluasi pembelajaran Akuntansi, jika nilai yang diperoleh siswa di atas KKM, maka pembelajaran Akuntansi dapat dilanjutkan dengan pengayaan. Namun, jika nilai di bawah KKM, pembelajaran 
Akuntansi dilanjutkan dengan remidi. Pengayaan merupakan pengalaman atau aktivitas siswa yang melebihi kriteria minimal yang ditentukan oleh kurikulum dan tidak semua peserta didik bisa melaksanakannya. Pembelajaran pengayaan bisa juga dihubungkan dengan aktivitas pemberian tugas terstruktur dan aktivitas mandiri secara tidak terstruktur. Sementara aktivitas remediasi dilakukan guna membantu peserta didik yang mengalami kesulitan dalam memahami materi pelajaran. Guru melakukan perubahan pada aktivitas pembelajaran Akuntansi berdasarkan kesulitan yang dialami oleh peserta didik. Beberapa kegiatan remidi yang dapat dilakukan misalnya pemberian tugas, kegiatan diskusi kelompok atau tutor sebaya. Seperti hasil penelitian dari Popa, et.al. (2012) bahwa pendekatan kegiatan pembelajaran Akuntansi yang dapat dilakukan yaitu tugas individu pekerjaan rumah (PR), tugas berpasangan dan tugas kelompok.

Kegiatan evaluasi pembelajaran Akuntansi dilakukan dengan menyiapkan bentuk model evaluasi khusus untuk pembelajaran Akuntansi, yaitu kinerja ilmiah dengan indikator: keaktifan siswa, rasa ingin tahu, kreativitas, kesungguhan belajar, tekun dan teliti. Penelitian dari Popa, et.al. (2012) menunjukkan siswa menggunakan kemampuan berpikir kritis dalam pembelajaran Akuntansi. Kemampuan berpikir kritis ini meliputi analisis, interpretasi, evaluasi, kesimpulan, dan penjelasan. Dari temuan penelitian dan hasil penelitian dari Popa, et.al. (2012) menunjukkan indikator yang digunakan dalam evaluasi pembelajaran Akuntansi sama-sama ditujukan untuk pembelajaran berpusat pada siswa.

\section{Simpulan}

Penyusunan rencana pelaksanaan Pembelajaran Akuntansi di SMK diawali dengan mempelajari standar isi, dan standar kompetensi. Disamping itu, juga perlu mempelajari silabus untuk penyesuaian kaldik; menyiapkan RPP. Dalam RPP terdiri dari identitas sekolah, mata pelajaran, kelas/ semester, SK (Standar Kompetensi), KD (kompetensi dasar), pertemuan dan alokasi waktu, indikator, tujuan pembelajaran, materi ajar, metode pembelajaran, langkah-langkah pembelajaran, alat/ bahan/ sumber belajar, penilaian. Membuat RPP, berdasarkan panduan format yang ditentukan dari MGMP dan disesuaikan kondisi sekolah. Menyebutkan standar kompetensi pelajaran akuntansi yang terdapat dalam silabus. Menyebutkan alat-alat praktik dalam alat/ bahan/sumber belajar seperti Kuitansi, buku besar, buku laporan keuangan, komputer, kalkulator, dll. Mengkonsultasikan dan mensyahkan Kepala Sekolah. Merevisi dan memperbaiki hasil konsultasi Kepala Sekolah. Menjilid RPP. Mengadministrasikan dan terakhir mendokumentasikan RPP.

Pengorganisasian pembelajaran Akuntansi di SMK, meliputi pengorganisasian materi pelajaran secara berurutan sesuai dengan acuan silabus, mengorganisir kalender akademik untuk pelaksanaan pelajaran praktik, mengorganisir kelas agar tidak terjadi kegaduhan dengan pengawasan dan sangsi, mengorganisir kesulitan-kesulitan materi pelajaran dan mencarikan penyelesaian.

Pada proses Pembelajaran Akuntansi di SMK kegiatan awal guru adalah menyampaikan salampembukaan, dilanjutkan dengan memperhatikan atau pengamatan kebersihan kelas. Melakukan absen kepada siswa. Cek tugas pekerjaan rumah, serta memotivasi siswa dengan cara menjelaskan daya guna materi Pelajaran Akuntansi untuk dimanfaatkan dalam kehidupan sehari-hari.

Pada pelaksanaan evaluasi Pembelajaran Akuntansi di SMK, kegiatan guru adalah membagikan soal tes kepada siswa. Siswa dapat menjawab buku pegangan siswa. Tes praktik pembelajaran Akuntansi ditunjukkan dengan kemampuan membuat laporan keuangan. Guru melakukan remidi kepada siswa yang nilainya di bawah KKM, sebaliknya guru memberikan pengayaan bagi siswa yang nilainya di atas KKM. Model evaluasi khusus Pembelajaran Akuntansi yaitu lembar kinerja ilmiah. 


\section{Daftar Pustaka}

Deviarti, Holly; Kurniawati, Heny; Sun, Yen; Sukendar, Heri. 2012. "The Convergency Of IFRS in Indonesia Accounting Standard: Do Vocational Schools Need To Change Their Curriculum?". International Journal of Information Technology and Business Management. Vol.2 No. 1, pp. 30-35.

Dockter, DuWayne L. 2012. "Problem-Based Learning In Accounting". American Journal Of Business Education. Vol. 5, No. 5, pp. 547-553.

Ezeagba, Charles Emenike. 2014. "The Problems in The Teaching and Learning Of Accounting As A Vocational Subject in Nigeria Secondary Schools". AFRREV STECH An International Journal of Science and Technology, Vol. 3, No. 9, pp. 208-226..

Fentim, Darkwa Bernard. 2014. "An Investigation on Teaching and Learning Resources/ Materials Used in Financial Accounting Lessons in SHS in Sunyani Municipality". International Journal of Research In Social Sciences, Vol. 4, No.2, pp. 54-92.

Kodoatie, Robert J. dan Sjarief, Roestam. 2010. Tata Ruang Air. Yogyakarta: Andi.

Miles, B Matthew \& A. Michael Huberman. 2008. Analisis Data Kualitatif. Jakarta: UI Press.

Moleong, Lexy Y. 2009. Metodologi Penelitian Kualitatif(Edisi Revisi). Bandung: PT. Remaja Rosdakarya.

Mulyono. 2008. Manajemen Administrasi \& Organisasi Pendidikan. Jogjakarta: Ar-Ruzz Media.

Popa, A.F.; Stanila, O.G.; Ponorica, A.G. 2012. "Impact of Changes in Methods of Teaching and Learning Accounting". Journal of Economics and Business Research, Vol. 18, No. 2, pp. 110-123.

Sagala, Syaiful. 2009. Manajemen Strategik dalam Peningkatan Mutu Pendidikan. Bandung: CV. Alfabeta.

Subadi, Tjipto, Khotimah, R.P., Sutarni, S. 2013. “A Lesson Study as A Development Model of Professional Teachers". International Journal of Education, Vol. 5, No. 2, pp. 102114.

Suryosubroto, B. 2009. Proses Belajar Mengajar di Sekolah. Jakarta: Rineka Cipta.

Sutama. 2010. Metode Penelitian Pendidikan Kuantitatif, Kualitatif, PTK, $R \&$ D. Surakarta: Fairuz Media.

Sutikno, Sobry. 2009. Belajar Pembelajaran Upaya Kreatif dalam Mewujudkan Pembelajaran yang Berhasil. Bandung: Prospect. 